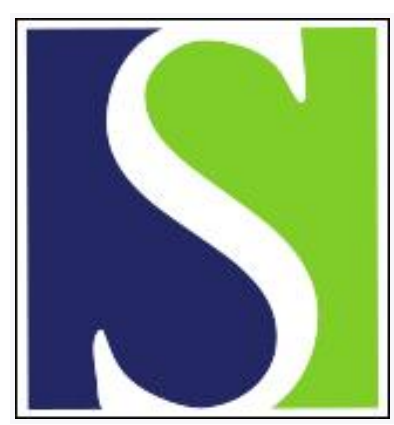

Scand J Work Environ Health 1991;17(2):91-94

https://doi.org/10.5271/sjweh.1722

Issue date: Apr 1991

Magnesium and calcium in drinking water and cardiovascular mortality.

by Rylander R, Bonevik H, Rubenowitz E

Affiliation: Department of Environmental Hygiene, University of Goteborg, Sweden.

This article in PubMed: www.ncbi.nlm.nih.gov/pubmed/2047817

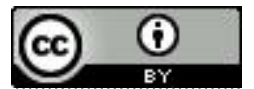




\title{
Magnesium and calcium in drinking water and cardiovascular mortality
}

\author{
by Ragnar Rylander, MD, Håkan Bonevik, MD, Eva Rubenowitz, MD1
}

\begin{abstract}
RYLANDER R, BONEVIK H, RUBENOWITZ E. Magnesium and calcium in drinking water and cardiovascular mortality. Scand J Work Environ Health 1991:17:91-4. Data on the hardness of drinking water were collected from 27 municipalities in Sweden where the drinking water quality had remained unchanged for more than 20 years. Analyses were made of the levels of lead, cadmium, calcium, and magnesium. These water-quality data were compared with the age-adjusted mortality rate from ischemic heart and cerebrovascular disease for the period 1969-1978. Lead and cadmium were not present in detectable amounts except in one water sample. A statistically significant inverse relationship was present between hardness and mortality from cardiovascular disease for both sexes. Mortality caused by ischemic heart disease was inversely related to the magnesium content, particularly for the men $(P<0.01)$. The rather small set of data supports results from previous studies suggesting that a high magnesium level in drinking water reduces the risk for death from ischemic heart disease, especially among men, although the possible importance of confounding factors needs further evaluation.
\end{abstract}

Key terms: cerebrovascular disease, ischemic heart disease, magnesium, water hardness.

Several epidemiologic investigations performed during recent decades have demonstrated an inverse relationship between water hardness and death from cardiovascular disease. The first observation was made in 1957 (1) and was subsequently elaborated upon in investigations in many other countries (2-4). A particularly relevant study was reported by Crawford et al (5), who followed the mortality rate in 11 English cities where the water hardness had changed between 1950 and 1960. Hardness had increased in five cities and decreased in six. Mortality from cardiovascular disease increased about $10 \%$ in the general population during the period of study. In the cities where hardness had decreased, mortality had increased by $20 \%$. In the cities where hardness had increased mortality had increased by $8.5 \%$.

Various suggestions have been offered concerning the causative agent for the relationship between death from cardiovascular disease and water hardness. Two principles have been discussed, namely, a toxic effect induced by the contamination of lead or cadmium or a protective effect from the water content of calcium or magnesium (2).

The importance of magnesium has been investigated in some previous field studies. Schroeder (6) found a negative relationship between mortality from heart disease among 45- to 64-year-old men and the amount of magnesium in drinking water $(\mathrm{r}=-0.30)$. In a Canadian study, Anderson (7) found a similar association, as did Leary et al (8) in South Africa $(\mathrm{r}=-0.68)$.

\footnotetext{
${ }^{1}$ Department of Environmental Hygiene, University of Göteborg, Göteborg, Sweden.
}

Reprint requests to: Professor R Rylander, Department of Environmental Hygiene, University of Göteborg, Box 33031, S-400 33 Göteborg, Sweden.
Punsar \& Karvonen (9) studied mortality from cardiovascular disease and water quality in two areas of Finland. They suggested that mortality from ischemic heart disease could be related to magnesium and chromium, but no relationship was found for sudden death. In a case-referent study of 30- to 64-year-old men with their first acute myocardial infarction, the myocardial disease rates were inversely related to the level of magnesium and fluoride in the drinking water (10). The risk ratio for low amounts of magnesium in drinking water was 2.0 for cases versus hospital referents and 4.7 for cases versus general population referents.

The present study was designed to evaluate the possible roles of lead, cadmium, magnesium, and calcium in cardiovascular mortality. Data on water quality were obtained from 27 Swedish municipalities, and the water was analyzed for its content of these elements. The data on water quality were compared with the mortality rates for ischemic heart disease and cerebrovascular disease among the male and female residents of the municipalities.

\section{Material and methods}

For the study, 44 Swedish municipalities were selected which had a range of water hardness from 0.8 to $20.7 \mathrm{dH}$ (German hardness degrees).

The waterworks in each municipality received a questionnaire requesting information on water hardness during the period 1955-1985 and on whether any changes had occurred in the water supply or treatment of the water during that period. Certain municipalities were excluded as changes in water quality (eg, change from well water to surface water) had been made during that period. The final material comprised hardness data from 32 municipalities. 
Table 1. Relationship between mortality from ischemic heart disease and cerebrovascular disease among the men and women in 27 municipalities in relation to water hardness and the water content of calcium and magnesium in the communities.

\begin{tabular}{|c|c|c|c|c|c|c|c|c|c|}
\hline & \multicolumn{3}{|c|}{ Hardness } & \multicolumn{3}{|c|}{ Calcium } & \multicolumn{3}{|c|}{ Magnesium } \\
\hline & $\begin{array}{l}\text { Correlation } \\
\text { coefficient }\end{array}$ & $\begin{array}{c}\text { Confidence } \\
\text { interval }\end{array}$ & $\begin{array}{c}P . \\
\text { value }\end{array}$ & $\begin{array}{l}\text { Correlation } \\
\text { coefficient }\end{array}$ & $\begin{array}{l}\text { Confidence } \\
\text { interval }\end{array}$ & $\begin{array}{c}P . \\
\text { value }\end{array}$ & $\begin{array}{l}\text { Correlation } \\
\text { coefficient }\end{array}$ & $\begin{array}{l}\text { Confidence } \\
\text { interval }\end{array}$ & $\begin{array}{l}\text { P. } \\
\text { value }\end{array}$ \\
\hline \multicolumn{10}{|c|}{$\begin{array}{l}\text { Ischemic heart } \\
\text { disease }\end{array}$} \\
\hline $\begin{array}{l}\text { Men } \\
\text { Women }\end{array}$ & $\begin{array}{l}-0.602 \\
-0.453\end{array}$ & $\begin{array}{l}-0.788--0.315 \\
-0.696--0.117\end{array}$ & $\begin{array}{l}0.001 \\
0.01\end{array}$ & $\begin{array}{l}-0.468 \\
-0.418\end{array}$ & $\begin{array}{l}-0.716--0.115 \\
-0.685--0.054\end{array}$ & $\begin{array}{l}0.01 \\
0.05\end{array}$ & $\begin{array}{l}-0.618 \\
-0.452\end{array}$ & $\begin{array}{l}-0.806--0.319 \\
-0.706--0.095\end{array}$ & $\begin{array}{l}0.01 \\
0.01\end{array}$ \\
\hline \multicolumn{10}{|c|}{$\begin{array}{l}\text { Cerebrovascular } \\
\text { disease }\end{array}$} \\
\hline $\begin{array}{l}\text { Men } \\
\text { Women }\end{array}$ & $\begin{array}{l}-0.483 \\
-0.367\end{array}$ & $\begin{array}{l}-0.715--0.155 \\
-0.638--0.014\end{array}$ & $\begin{array}{l}0.05 \\
0.05\end{array}$ & $\begin{array}{l}-0.515 \\
-0.323\end{array}$ & $\begin{array}{l}-0.745--0.176 \\
-0.622-0.056\end{array}$ & $\begin{array}{l}0.05 \\
0.12\end{array}$ & $\begin{array}{l}-0.165 \\
-0.143\end{array}$ & $\begin{array}{ll}-0.507- & 0.222 \\
-0.490- & 0.243\end{array}$ & $\begin{array}{r}0.19 \\
>0.40\end{array}$ \\
\hline
\end{tabular}

\section{$\mathbf{R R}$}

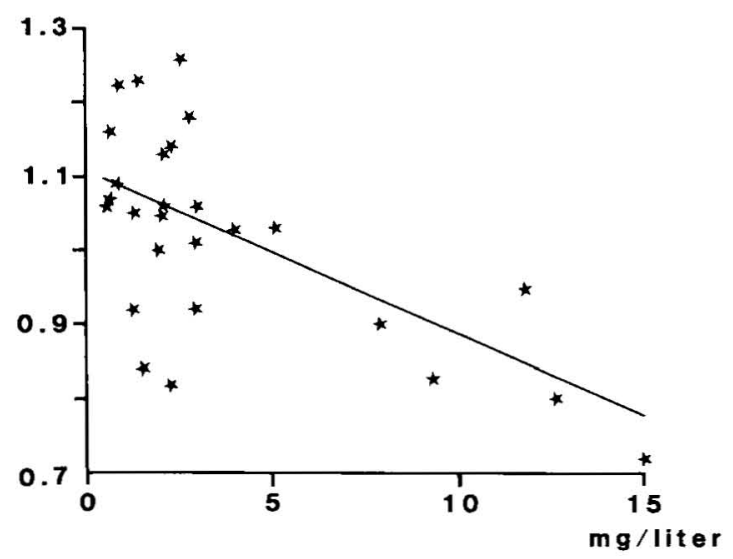

Figure 1. Relation between mortality from ischemic heart disease among the men [relative risk (RR) in comparison with the whole of Sweden] and the magnesium level in the drinking water of 27 Swedish municipalities.

Water samples were requested from these areas for the determination of the levels of calcium, magnesium, lead, and cadmium. The analyses were made at Chalmer's Institute of Technology with atomic absorption spectrophotometry using the flame technique (magnesium and calcium) and oven technique (lead and cadmium). The detection threshold was $1 \mu \mathrm{g} / \mathrm{l}$ for lead and $0.5 \mu \mathrm{g} / 1$ for cadmium. Complete analysis data were obtained from 27 municipalities.

Data were obtained on mortality from ischemic heart disease and cerebrovascular disease (International Classification of Diseases, codes 410-414 and 430-438) in these 27 municipalities for the period 1970-1980 from the Swedish Planning and Rationalization Institute for Health and Social Services. The data for each municipality were standardized for age groups in 10-year intervals and related to mortality data for the whole country during the period $1969-1978$. The total population of the municipalities ranged between 7794 and 100875 inhabitants (mean values 1969 to 1978). The total number of inhabitants in the municipalities was 809655 .

The mortality index for each municipality was compared with the water hardness data and the results of the analysis regarding calcium, magnesium, lead, and cadmium.

The relationship between the water-quality variables and mortality was tested with a special test designed for problems in which environmental factors and Poisson distributed variables are studied (11). The statistical model used has the realistic property that the expected numbers of deaths are allowed to vary between municipalities because of reasons other than water quality, age, or sex distribution. The size of the municipalities was also taken into account. Two-sided tests were used.

\section{Results}

The levels of lead and cadmium were below the detection threshold in all the water samples analyzed except one, in which $1.05 \mu \mathrm{g}$ of cadmium per liter of water was determined.

The hardness of the different water samples ranged between 0.80 and $20.7 \mathrm{dH}$. The amount of calcium ranged from 3.4 to $131 \mathrm{mg} / \mathrm{l}$ and that of magnesium from 0.57 to $15.0 \mathrm{mg} / \mathrm{l}$. There was a high correlation between calcium and hardness (0.93). Magnesium, however, was not as highly correlated with either hardness $(0.71)$ or calcium $(0.55)$.

Table 1 shows the correlation coefficients and statistical significance for the relation between water hardness and the amount of calcium and magnesium with mortality from ischemic heart disease and cerebrovascular disease. An inverse relationship was observed for the relation between hardness and mortality from ischemic heart disease among the men. The same relationship, although less pronounced, was found for the women. Mortality from cerebrovascular disease was also inversely related to water hardness, although the relationships were less pronounced. Magnesium was inversely correlated with ischemic heart disease mortality among the men and the women. For cerebrovascular disease, calcium showed the strongest inverse relation for the men, but the relation for the women was not statistically significant.

The relative risk for mortality from ischemic heart disease among the men in the different municipalities and the magnesium content in their drinking water is illustrated in figure 1. 


\section{Discussion}

The analyses of the water samples were made at a time (1988) later than the period during which the hardness data were collected (1970-1980). In the design of the study, however, only municipalities in which the water quality or source had not varied during the last two decades were included. It is thus likely that the 1988 analysis also reflected the magnesium and calcium content over the time from which the mortality data were obtained.

The results from the study reconfirm the previously observed inverse relationships between mortality from cardiovascular disease and water hardness. The relationship was stronger for the men than the women, as has also been found in previous studies (2).

The hypothesis that toxic materials in drinking water can be related to cardiovascular mortality could not be tested in this study, as significant amounts of lead or cadmium were not found in the water of the municipalities examined.

The results demonstrated a statistically significant relationship between the amount of magnesium and ischemic heart disease but not cerebrovascular disease. The possible importance of confounding factors must be considered. Cardiovascular disease is more common in built-up areas. However the populations of the municipalities ranged in size between about 8000 and 100000 , and there was no relationship between population size and mortality from ischemic heart disease or cerebrovascular disease.

Magnesium in the drinking water showed a tendency towards lower levels in municipalities in the north of Sweden, but this geographic distribution was not uniform. Smoking habits represent an important possible confounder, but a covariation between the extent of smoking in different municipalities and the magnesium content of the water is not likely. It is also unlikely that there should be a direct relation between other traditional risk factors such as consumption of fat and the level of magnesium in drinking water; however the problem of possible confounding factors should be further evaluated.

The relation between ischemic heart disease in men and water magnesium levels illustrated in figure 1 is probably complex. For the municipalities with low levels of magnesium in the water, both high and low mortality was found. This variation could be dependent upon random variation or a variation in traditional risk factors such as diet and smoking habits. The low mortality in all the municipalities with high levels of magnesium $(>8 \mathrm{mg} / \mathrm{l})$ suggests that magnesium could have a protective effect stronger than the negative influence of the traditional risk factors.

The significant association between mortality from ischemic heart disease among the men and the amount of magnesium in the water is supported by knowledge of the functions of magnesium. It is an activator for several enzyme systems and is essential for cell mem- brane permeability and neuromuscular excitability. A lack of magnesium leads to a decrease in the concentration of intracellular potassium and an increase in calcium levels (12). Magnesium deficiency may increase the risk for cardiac arrhythmia (13) and the contractility of blood vessels, as shown in animal experiments $(14,15)$.

The question has been raised of how the relatively small intake of magnesium via water, about $10 \%$ of the total intake, can have a critical significance for the amount of magnesium in the body and heart muscle. However, several studies support this hypothesis. Anderson et al (16) investigated 54 cases of accidental death in cities with soft water and 29 cases in cities with hard water. A significantly lower amount of heart muscle magnesium was found in the cases in cities with soft water. Crawford \& Crawford (17) showed that the amount of magnesium in coronary arteries was lower among persons who lived in areas with low magnesium levels.

Only limited information is available regarding the uptake of magnesium in food from the intestines. It may be that magnesium in a dissociated form in water has a higher uptake rate than magnesium in food. This hypothesis is supported by the results of two experimental pilot studies $(18,19)$, but more extensive investigations are required before final conclusions can be drawn.

In order to evaluate further the question of the proportional uptake of magnesium from water and food, studies need to be made in which the body balance of magnesium is prospectively measured in individuals with controlled intake of magnesium in water and food. Such studies are in progress.

In summary, the present study suggests that mortality from ischemic heart disease, particularly among men, can be related to the amount of magnesium in drinking water. Further studies on the relative role of different sources of magnesium in food and water, as well as experimental studies, are needed before these conclusions can be transformed into public health practice.

\section{Acknowledgments}

This study was supported by funds from Wilhelm and Martina Lundgren's Research Fund and the Medical Society of Göteborg, Sweden.

The magnesium analyses were performed by Ms E Axen, Chalmer's Institute of Technology, Göteborg, Sweden, and the statistical analysis was carried out by A Oden, PhD.

\section{References}

1. Kobayashi J. On geographical relations between the chemical nature of river water and death rate from apoplexy. Berichte des Ohara Instituts für landwirtschaft- 
liche Biologie Okayama University 1957;11:12-21.

2. Comstock GW. The epidemiological perspective: water hardness and cardiovascular disease. J Environ Pathol Toxicol 1980;3:9-25.

3. Perry HM, Perry EF. Cardiovascular disease: the effect of hard and soft water. In: Böström $\mathrm{H}$, Ljungstedt $\mathrm{N}$, ed. Skandia international symposia: race elements in health and disease. Stockholm: Almqvist \& Wiksell International, 1985;193-220.

4. Neri LC, Johansen HL. Water hardness and cardiovascular mortality. Ann NY Acad Sci 1978;304:203-219.

5. Crawford MD, Garner MS, Morris JN. Changes in water hardness and local death rates. Lancet 1971;2:327-9.

6. Schroeder HA. Relation between mortality from cardiovascular disease and treated water supplies. JAMA 1960;172:1902-8.

7. Anderson TW. Water hardness, magnesium and ischemic heart disease. NS Med Bull 1977;56:58-61.

8. Leary WP, Reyes AJ, Cockett CJ, et al. Magnesium and deaths ascribed to ischemic heart disease in South Africa. S Afr Med J 1983;64:775-6.

9. Punsar S, Karvonen MJ. Drinking water quality and sudden death: observations from West and East Finland. Cardiology 1979;64:24-34.

10. Luoma H, Aromaa A, Helminen S, et al. Risk of myocardial infarction in Finnish men in relation to fluoride, magnesium and calcium concentration in drinking water. Acta Med Scand 1983;213:171-6.

11. Wahlström J, Witt-Engerström I, Mellquist L, Anvret M, Odén A. Rett syndrome related to fragile X (P22) in caffeine-induced lymphocyte culture. Brain Dev 1990;12:128-130.
12. Gunther T. Magnesium: cardiovascular biochemistry. Magnesium Bull 1986;8:136-9.

13. Eisenberg MJ. Magnesium deficiency and cardiac arrythmias. NY State J Med 1986;86:133-5.

14. Turlapaty PDMV, Altura BM. Magnesium deficiency produced spasms of coronary arteries: relationship to etiology of sudden death ischemic heart disease. Science 1980;208:198-200.

15. Altura BM, Altura TB, Gebrewold A. Magnesium deficiency and hypertension - correlation between magnesium deficient diets and microcirculatory changes in situ. Science 1984;223:1315-17.

16. Anderson TW, Neri LC, Schreiberg HD. Ischaemic heart disease, water hardness and myocardial magnesium. Can Med Assoc J 1975;113:199-203.

17. Crawford T, Crawford MD. Prevalence and pathological changes of ischaemic heart disease in a hard-water and in a soft-water area. Lancet 1967;1:229-32.

18. Binnerts WT, Löwik MRH, Groot EM. On the importance of $\mathrm{Mg}$ in drinking water. In: Trace element analytical chemistry, medicine and biology. Berlin: DeGruyter, 1983;2:287-93.

19. Lowik MRH, Groot EM, Binnerts WT. Magnesium and public health: the impact of drinking water. In: The University of Missouri. Trace substances in environmental health: proceedings of University of Missouri's annual conference on trace substances in environmental health. Columbia, MO: University of Missouri, 1982; 16:189-195.

Received for publiation: 26 March 1990 